\title{
ラットの血清コレステロール濃度に及ぼす 緑葉タンパク質給与の影響
}

\author{
曹永 守, 堀 米隆 男 \\ 坂口英, 内田仙二 \\ 岡山大学農学部 \\ Effect of Feeding of Leaf Proteins on Serum Cholesterol \\ Concentration in Rats \\ Young-Su CHO, Takao HORIGOME, Ei SAKAGUCHI \\ and Senji UCHIDA \\ Faculty of Agriculture, Okayama University, Okayama 700
}

\begin{abstract}
Nippon Eiyō Shokuryō Gakkaishi (J. Jpn. Soc. Nutr. Food Sci.) 41, 127 132 (1988)
Leaf proteins (LPs) were prepared by heating the green juice from Italian ryegrass and alfalfa at $80-85^{\circ} \mathrm{C}$ and were compared with casein and soybean protein isolate for their hypocholesterolemic action in Wistar male rats. Each protein source was incorporated into a cholesterol-free, low-fat diet to provide a protein level of $20 \%$. The values of serum total and LDL-cholesterol in rats fed Italian ryegrass and alfalfa LPs were significantly lower than those of rats fed casein and were comparable to those of rats fed soybean protein. $p$-Coumaric, ferulic and caffeic acids and coumestrol, which were presumed to be contaminants in LPs, had no lowering effect on serum total and LDL-cholesterol. In addition, it was shown that the ratios of Arg/Lys and Met+Cys/Gly of both the LPs were very close to those of soybean protein. These data suggest that both of the LPs tested appear to function in a similar way to soybean protein in their hypocholesterolemic action.
\end{abstract}

(Received August 22, 1987)

アテローム性動脈硬化は血清コレステロール(Chol), とくに低密度りポタンパクコレステロール (LDL-Chol) 濃度と正の相関があることは広く認められているところ である。一方，大豆タンパク質の摄取は，高脂血症患者 の血清 Chol を降下させることが知られるようにな $\eta^{1 \sim 3)}$, 動脈硬化の防止の点から大豆タンパク質に対す る関心が高まっている。

さて, 牧草から瀻維部分を分離して得られる緑葉タン パク質 leaf protein (LP) は製造方法が良ければ大豆タ ンパク質に匹敵する栄養価を有していることが明らかに されれ，また，世界的なタンパク質源の逼迫状況から見 て，LP を食品タンパク質として利用することが望まれ ている。それゆえ，LP の栄盖特性を明らかにすること は意義があると考えられるので，上記の状況にかんが み，LP の血清 Chol に対する作用について, ラットを 用い，カぜイン，大豆タンパク質と比校検討した。ま
た，LP にはコーヒー酸等のフェノールカルボン酸類が 混在していることが推測され，また，アルファルファ LP にはクメストロールが含まれることが報告されてい るので56)，フェノールカルボン酸およびクメストロー ルの血清 Chol 降下作用の有無についても検討した。

\section{実 験 方 法}

\section{LP の調製}

LP の調製に用いた牧草はイネ科のイタリアンライグ ラス (Lolium maltiflorum Lam.) とマメ科のアルファ ルファ (Medicago sativa L.) である。イタリアンライ グラスは出穂前, アルファルファは開花前の茎葉を供し た。生草をカッターにて切断後, 材料草の重量の約半量 の水を加えながらチョッハーにて破砕し，破碎物を麻袋 に入れ，手動圧搾機にて圧㩁して緑色の汁液と瀻維部分 のプレスケーキとに分離した。緑葉汁液は $\mathrm{pH}$ を調整す

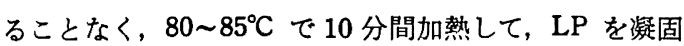
させた。 $4^{\circ} \mathrm{C}$ の冷所に一夜放置後, LP カードをナイロ 
Table 1. Composition of experimental diets (\%).

\begin{tabular}{lcccc}
\hline \hline \multicolumn{1}{c}{ Ingredient } & $\begin{array}{c}\text { Italian ryegrass } \\
\text { leaf protein diet }\end{array}$ & $\begin{array}{c}\text { Alfalfa leaf } \\
\text { protein diet }\end{array}$ & Casein diet & $\begin{array}{c}\text { Soybean } \\
\text { protein diet }\end{array}$ \\
\hline Italian ryegrass LP & 29.3 & - & - & - \\
Alfalfa LP & - & 29.5 & - & - \\
Casein & - & - & 22.8 & - \\
Soybean protein & - & - & - & 24.0 \\
Corn oil & 1.0 & 1.0 & 1.0 & 1.0 \\
Mineral mixturea) & 2.2 & 1.0 & 3.3 & 3.1 \\
Vitamin mixtureb) & 1.0 & 0 & 1.0 & 1.0 \\
Cellulose powder & 0 & 66.5 & 3.0 & 2.0 \\
Sucrose & 66.5 & 68.9 & 68.9 \\
\hline \hline
\end{tabular}

a) Phillips-Hart's salt mixture. ${ }^{28)}$

b) Vitamin mixture (per $1 \mathrm{~g}$ ): $\mathrm{VB}_{1}$ nitrate $0.2 \mathrm{mg}, \mathrm{VB}_{2} 0.3 \mathrm{mg}$, nicotinamide $2 \mathrm{mg}$, pyridoxine- $\mathrm{HCl} 1 \mathrm{mg}$, Ca pantothenate $1 \mathrm{mg}$, VC $7.5 \mathrm{mg}$, DL- $\alpha$-tocopherol acetate $5 \mathrm{mg}$, inositol $10 \mathrm{mg}$, choline chloride 0.1 $\mathrm{g}$, retinol palmitate $500 \mathrm{I} . \mathrm{U}$., ergocalciferol $100 \mathrm{I} . \mathrm{U} ., \mathrm{VK}_{3} 5 \mathrm{mg}$, folic acid $0.1 \mathrm{mg}$, cyanocobalamine $0.5 \mu \mathrm{g}$, by reference to NRC-allowances. ${ }^{29}$ )

ン濾布を敷いたブフナーロート上に移し吸引し，できる 限り水分を除去した。得られた LPカードから, 水分, リピト，色素類を除くとともに，アルファルファLPの 場合には，さらにサポニンを除去するため，LP カード をつセトンにて室温で繰り返し抽出し，試料として用い た。

\section{2. 実験動物と飼育法}

1）LP の動物試験 5 週齢のウィスター系雄ラット （日本クレア）を 3 日間, 飼育用飼料（日本クレア, CE-2) で飼育後, 各群 5 頭ずつに分け，個別のゲージで 21 日間, 試験飼料で飼育した。飼育環境は温度 $22 \pm 2^{\circ} \mathrm{C}$ とし，7:00に点灯，19:00に消灯するように照明を七 ットした。試験飼料は粗タンパク質含量が $20 \%$ となる ようにそれぞれのタンパク質試料を混合しだ。タンパ ク質試料として LP のほか，カゼイン（ハムマーステイ ン,メルク社製)および分離大豆タンパク質（フジプロ $\mathrm{R}$ ，フジピュリナプロテイン社製)を用いた。なお，大 豆タンパク質はサポニン除去のため $80 \%$ エタノールに て室温で 4 回抽出したものを供した。飼料組成は Table 1 に示すと拈りであるが，セルロース粉末およびミネラ ル混合物の量はタンパク質試料の可溶性無窒素成分およ び粗灰分の含量 (Table 2) によって調節した。飼育期間 の最後の 3 日間の䔬を採集し, タンパク質の見かけの消 化率を測定した。また，最終日の夜 9 時に残した飼料を 撤去し, 約 12 時間絶食後, エーテル麻酔したラットの 頸静脈より採血して分析に供した。イタリアンライグラ ス LP とアルファルファLP の動物試験は実験 1，2 として，それぞれ独立して実施した。

2)フェノールカルボン酸およびクメストロールの動
物詓験 試験に供したフェノールカルボン酸は ール酸、フェルラ酸, コーヒー酸の 3 種類である。使用 ラットおよび飼育条件は LP の動物試験と同じである。

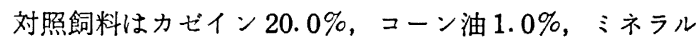
混合物 $4.0 \%$ ，ビタミン混合物 $1.0 \%$ ，七ルロース粉末 $2.0 \%$ ，ショ糖 $72.0 \%$ よりなる無コレステロール飼料で あり,この飼料に、フェノールカルボン酸をそれぞれ $0.2 \%$ ，クメストロールを $50 \mathrm{ppm}$ 混合した 4 種類の試 験飼料を調製した。飼育期間，採血方法なども，LPの 場合と同じである。

\section{3. 化学分析および試菜}

血清中の総 Chol は Pearson らの方法》, 高密度リポ タンパク-Chol (HDL-Chol) はヘパリン・マンガン沈澱 法による HDL-Chol テスト・キット (和光純薬), トリ グリセリドは酵素法によるトリグリセリドGテスト・キ ット（和光純薬）によって測定した。LDL-Chol は総 Chol より HDL-Chol を差し引いて求めた。肝蔵脂質の 抽出は Kates の方法8) により行い，最終クロロホルム 溶液について Pearson らの方法》により総 Chol を測 定した。動物試験に用いた コーヒー酸は東京化成の特級市肘品, クメストロールは Pfaltz \& Bauer 社 (U.S.A.) 製品である。タンパク質 試料のアミノ酸分析は既報出のとおり行った。粗タンハ・ ク質, 粗灰分等は常法9"によった。

\section{4. 有意差検定}

平均値間の有意差検定は分散分析（F-埃定）を行い， 個々の群間の有意差の検定は Tukey の方法により行っ た。 
Table 2. Composition of protein sources.

\begin{tabular}{|c|c|c|c|c|c|}
\hline \multicolumn{2}{|c|}{ Protein source } & $\begin{array}{c}\text { Italian ryegrass } \\
\text { leaf protein }\end{array}$ & $\begin{array}{l}\text { Alfalfa } \\
\text { leaf protein }\end{array}$ & Milk casein & $\begin{array}{l}\text { Soybean } \\
\text { protein }\end{array}$ \\
\hline Moisture & $(\%)$ & 8.72 & 10.42 & 5.63 & 6.97 \\
\hline Nitrogen* & $(\%)$ & 11.98 & 12.12 & 14.76 & 15.72 \\
\hline \multicolumn{2}{|c|}{ Conversion factor } & 6.25 & 6.25 & 6.38 & 5.71 \\
\hline Crude protein & $(\%)$ & 74.88 & 75.75 & 94.17 & 89.76 \\
\hline Crude ash* & (\%) & 6.80 & 7. 85 & 3. 28 & 4.19 \\
\hline \multicolumn{2}{|c|}{ Nitrogen-free extract* $(\%)$} & 18. 32 & 16.40 & 2.55 & 6.05 \\
\hline Arginine & $(\mathrm{g} / 16 \mathrm{~g} \mathrm{~N})$ & 6.3 & 6.3 & 4.0 & 7.2 \\
\hline Lysine & $(\mathrm{g} / 16 \mathrm{~g} \mathrm{~N})$ & 6.2 & 6.1 & 8.1 & 6.4 \\
\hline \multicolumn{2}{|l|}{$\mathrm{Arg} /$ Lys ratio } & 1.02 & 1.03 & 0.49 & 1.13 \\
\hline Methionine & $(\mathrm{g} / 16 \mathrm{~g} \mathrm{~N})$ & 2.4 & 2.1 & 3.0 & 1.2 \\
\hline Cystine & $(g / 16 \mathrm{~g} \mathrm{~N})$ & 1.2 & 0.9 & 0.5 & 1.3 \\
\hline Glycine & $(\mathrm{g} / 16 \mathrm{~g} \mathrm{~N})$ & 5.6 & 5.8 & 2.1 & 4.4 \\
\hline \multicolumn{2}{|c|}{ Met + Cys/Gly ratio } & 0.64 & 0.52 & 1.67 & 0.57 \\
\hline
\end{tabular}

* Value on dry matter basis.

\section{実騃結果および考察}

\section{1. タンパク質試料の化学組成}

Table 2 に実験に用いたタンパク質試料の組成を示し た。イタリフンライグラス, アルファルファLPは乾物 中，粗タンパク質をそれぞれ 74.88，75.75\% 含み，LP 試料としては粗タンパク質含量が高いが，カゼイン，大 豆タンパク質よりはかなり低い。これらの LP 試料には 粗瀻維, 粗脂肪はほとんど含まれていないので, 粗タン パク質, 粗灰分以外の成分は可溶性無 $\mathrm{N}$ 物に相当する。 しかし, LP は程度の差があるが褐変していること, LP のエタノール抽出夜の吸収スペクトルは $300 \sim 330 \mathrm{~nm}$ に吸収を有することから、コーヒ一酸、p-クマール酸な どのフェノールカルボン酸の存在が推測される。したが って LP の可溶性無N物画分には種々のフェノール性化 合物が含まれると考えられる。つぎに，タンパク質の Chol 降下作用に了ミ/酸組成, とくに Arg/Lys 比か;関 連をもっていることが報告されているが10 12)，この点か ら見ると両 LP の Arg/Lys 比が 1.02，および 1.03 で 大豆タンパク質 (1.13) 飞近い。また,グリシンと含硫ア ミ 酸との相対的含量も血清 Chol 降下因子の一つとす る報告も多いが(3)-15)，この点においても，Table 2 に見 られるとおり両 LP とも大豆タンパク質に近い。なお， LP の制限てミ八酸はカゼイン，大豆タンパク質と同じ く,メチオニンであるが(16), 飼料中, タンパク質レヘル 20\%とした場合は, メチオニンおよび含硫フミノ酸の必 要量を満たすことになるので, ラットの成長におよぼす 制限アミノ酸の影辢はないるのと考える。

\section{LP の血清コレステロール降下作用}

Table 3 には実験 1 および 2 の動物試験の結果を示し た。実験 2 の大豆タンパク質群の結果は 2 頭の平均で参 考值として示した。実験 1 のイタリアンライグラス LP, カゼイン, 大豆タンパク質 3 群間の飼料攝取量, 体重增 加量には有意差がなかったが，実験 2 においては，アル ファルファLP 群の飼料摂取量, 体重增加量はカゼイン 群に比し有意に低かった。アルファルファLP群の摂取 量の低い理由は不明であるが，この摂取量の低いこと と, 後述するよらにタンパク質消化率の低いことが体重 增加量の少ない原因と考兄られる。見かけのタンパク質 消化率は実験 $1 ， 2$ を通して LP 群が最も低く，カゼイ ン群か最も高かった。LP の消化率の低い理由は，おそ らくタンパク質自体の性質に基づくといらょり，混在物 質の影響によるものと考兄られ，とくにアルファルファ LP の消化率の低い原因は比較的，熱に安定なトリプシ ンインヒビターの混在によると推測される ${ }^{17}$ 。つづに, 血清 Chol についてみると, 実験 $1 ， 2$ ともに LP 群の 総 Chol おょび LDL-Chol はカゼイン群より有意に低 く，大豆タンパク質群に近かっだ。HDL-Chol はカゼイ ン群が高いが，数值のばらつきが大きく，実験 $1 ， 2$ と もに LP 群とは有意差が認められなかった。このよらに LP には動脈硬化症と正の相関 関係のある総 Chol, LDL-Chol 降下作用が認められた。Neves ら ${ }^{18)}$ はアル ファルファ LP をラットに 28 日間給与し, 血清 Chol 降下作用を認めることができなかったと報告している。 しかし, Neves らの用いた試験飼料は低タンパク質 （飼料中 10\%）であるとともに大豆油を $10 \%$ 含んでお 
Table 3. Body-weight gain, protein digestibility and serum and liver lipids of rats given leaf protein, casein or soybean protein (Mean values with their S.D. for five rats/ group).

\begin{tabular}{|c|c|c|c|c|c|c|}
\hline \multirow[b]{2}{*}{ Dietary protein } & \multicolumn{3}{|c|}{ Experiment 1} & \multicolumn{3}{|c|}{ Experiment 2} \\
\hline & $\begin{array}{l}\text { Italian ryegrass } \\
\text { leaf protein }\end{array}$ & Casein & $\begin{array}{c}\text { Soybean } \\
\text { protein }\end{array}$ & $\begin{array}{c}\text { Alfalfa } \\
\text { leaf protein }\end{array}$ & Casein & $\begin{array}{c}\text { Soybean } \\
\text { protein }\end{array}$ \\
\hline Feed intake (g/21 days) & $345 \pm 18$ & $327 \pm 12$ & $345 \pm 3$ & $279 \pm 4^{a)}$ & $287 \pm 3^{b)}$ & $288^{*}$ \\
\hline Weight gain ( $\mathrm{g} / 21$ days) & $120.4 \pm 6.7$ & $116.3 \pm 5.7$ & $110.3 \pm 5.2$ & $76.3 \pm 2.1^{\mathrm{a})}$ & $96.5 \pm 5.5^{b)}$ & 77.0 \\
\hline $\begin{array}{l}\text { Protein } \\
\text { digestibility }(\%) \\
\text { Serum lipids }(\mathrm{mg} / \mathrm{dl})\end{array}$ & $94.7 \pm 0.2^{a)}$ & $99.6 \pm 0.1^{\mathrm{c})}$ & $98.6 \pm 0.1^{b)}$ & $82.4 \pm 1.3^{a)}$ & $97.9 \pm 0.3^{b)}$ & 92.5 \\
\hline Total cholesterol & 102. $3 \pm 16.1^{\text {a) }} 1$ & $143.4 \pm 17.5^{\mathrm{b})}$ & $90.8 \pm 2.8^{a)}$ & $97.1 \pm 4.1^{2)} 1$ & $142.1 \pm 14.0^{\mathrm{b})}$ & 95.0 \\
\hline HDL-cholesterol & 43. $\left.0 \pm 11.3^{a) b}\right)$ & $63.7 \pm 14.1^{\mathrm{b})}$ & $44.8 \pm 5.6^{2)}$ & $34.9 \pm 9.2$ & $49.7 \pm 7.1$ & 33.6 \\
\hline LDL-cholesterol & $59.2 \pm 8.5^{b)}$ & $79.7 \pm 12.1^{c)}$ & $45.9 \pm 4.8^{\mathrm{a})}$ & $62.2 \pm 4.4^{a)}$ & $92.4 \pm 8.0^{\mathrm{b})}$ & 61.4 \\
\hline Triglyceride & $85.9 \pm 24.9^{b)}$ & 58. $\left.5 \pm\left(6.9^{a}\right) b\right)$ & $47.7 \pm 11.1^{a)}$ & 104. $3 \pm 20.21$ & $136.6 \pm 33.1$ & 99.8 \\
\hline $\begin{array}{l}\text { Liver, wet weight } \\
\text { (g/100 g body-wt.) }\end{array}$ & $2.96 \pm 0.03^{a)}$ & $3.78 \pm 0.22^{\mathrm{b})}$ & $4.30 \pm 0.78^{b)}$ & $3.42 \pm 0.13^{a)}$ & $4.04 \pm 0.03^{b)}$ & 4.94 \\
\hline \multicolumn{7}{|l|}{ Liver lipid } \\
\hline Cholesterol (mg/g) & $2.27 \pm 0.10^{\mathrm{b})}$ & $2.54 \pm 0.23^{b)}$ & $1.20 \pm 0.49^{a)}$ & $1.94 \pm 0.15$ & $2.13 \pm 0.12$ & 1.33 \\
\hline $\begin{array}{l}\text { Cholesterol } \\
\text { (mg/100 g body-wt.) }\end{array}$ & $6.71 \pm 0.65^{a)}$ & $9.60 \pm 1.33^{b)}$ & $5.16 \pm 1.10^{a)}$ & $6.63 \pm 1.03^{a)}$ & $8.60 \pm 0.65^{b)}$ & 6.57 \\
\hline
\end{tabular}

a)b)c) Values with different superscripts in the same horizontal line of each experiment are significantly different at $p<0.05$. * Mean value for two rats.

り，タン゙パク質の Chol 降下作用を試験するには不適当 な条件 ${ }^{19)}$ であったために，われわれの結果と異なるもの となったと考えられる。一方, Sautier ら ${ }^{20)}$ は同じくア ルファルファ LP をラットについて試験し, タンパク質 $20 \%$ ，コーン油 $5 \%$ 飼料組成で，有意差はないものの LP に血清 Chol を降下させる傾向のあることを報告し ている。なお, アルファルファ LP 群の体重増加量は, 前述したとおりカゼイン群のそれに対し約 $20 \%$ 少なく， このことが血清 Chol の低レベルの原因となっていると も考えられる。しかし，小麦グルテンを等量含む飼料を 給与し, 体重增加量に大きな差異を生じさせた場合で も, ラットの血清 Chol 濃度に有意差を生じるほどの影 響を与えなかった報告21) もあり，また，Carroll22) は， ウサギに種々の飼料を給与して行った実験であるが，体 重增加量と血清 Chol 濃度とは関連ないと述べている。 これらの報告を参考にして考えれば, 今回の実験の体重 增加量の差異は, それほど極端ではないので, アルファ ルファ群の血清 Chol の降下は主としてLP の作用によ るものと判断される。肝臟の湿重量は実験 1,2 を通 し， LP 群が他の 2 群に対し有意に低く，また，カゼイ ン群と大豆タンパク質群の間では差異は認められない。 また, 肝 Chol 濃度については, LP 群とカゼイン群の 間では有意差はなく, 大豆タンパク質群は他の 2 群より も有意に低い。しかし, 肝 Chol 総量で比較すると, 実験
1 ではカゼイン群が他の 2 群に対し有意に高くなった。 LP 群は大豆タンパク質群より高いが，有意ではない。 この傾向は実験 2 でも認められる。これらのことは, 肝 Chol 総量と血清 Chol 濃度と関連のあることを示すと ともに, LP と大豆タンパク質の血清 Chol 降下作用の 機構に何らかの類似性のあることをらかがわせる。

3. フェノールカルポン酸, クメストロールの血清コ レステロールに対する作用

p-クマール酸, フェルラ酸, コーヒー酸およびクメス トロールを無コレステロール・低脂肪飼料に混合して試 験を試みた結果を Table 4 に示した。3 種類のフェノー ルカルボン酸を飼料に $0.2 \%$, クメストロールを $50 \mathrm{ppm}$ 混合した場合には, 対照群に比べ飼料摂取量は, いずれ の化合物給与群においても差異はなく, フェルラ酸群を のぞき体重増加量にも低下がみられない。Jung と Fahey は23), p-クマール酸, あるいはフェルラ酸をラットに給 与した場合, 飼料に $0.5 \%$ 添加により, すでに体重増加 量が減少し，1.5\% 添加により摂取量が低下するが, 2.0 \%添加でも乾物消化率, タンパク質消化率は低下しない ことを報告している。今回の実験では消化率は測定して いないが、これらのことから考え，フェルラ酸 $0.2 \% に$ よる体重増加量の低下は何らかの代謝障害によると推察 される。なお，肝湿重量にはすべての群にわたって有意 差は認められなかった。つぎに, 血清 Chol に対する影 
Table 4. Body-weight gain, feed intake, liver weight and serum lipids of rats given some phenolic acids and coumestrol (Mean values with their S.D. for five rats/group).

\begin{tabular}{lccccc}
\hline \hline Treatment & Control & $\begin{array}{c}p \text {-Coumaric } \\
\text { acid } \\
0.2 \%\end{array}$ & $\begin{array}{c}\text { Ferulic } \\
\text { acid } \\
0.2 \%\end{array}$ & $\begin{array}{c}\text { Caffeic } \\
\text { acid } \\
0.2 \%\end{array}$ & $\begin{array}{c}\text { Coumestrol } \\
50 \mathrm{ppm}\end{array}$ \\
\hline Feed intake (g/21 days) & $-247 \pm 2$ & $250 \pm 1$ & $247 \pm 2$ & $249 \pm 1$ & $248 \pm 3$ \\
Weight gain (g/21 days) & $77.6 \pm 1.7$ & $76.5 \pm 3.1$ & $72.8 \pm 2.0^{*}$ & $77.7 \pm 2.1$ & $74.7 \pm 3.3$ \\
$\begin{array}{l}\text { Liver weight } \\
\text { (g/100 } \mathrm{g} \text { body weight) }\end{array}$ & $4.77 \pm 0.25$ & $4.56 \pm 0.12$ & $4.84 \pm 0.22$ & $4.48 \pm 0.29$ & $4.46 \pm 0.32$ \\
$\begin{array}{l}\text { Serum lipids (mg/dl) } \\
\text { Total cholesterol }\end{array}$ & & & & & \\
HDL-cholesterol & $119.7 \pm 18.8$ & $119.4 \pm 12.5$ & $134.5 \pm 15.2$ & $115.6 \pm 4.7$ & $129.1 \pm 17.0$ \\
LDL-cholesterol & $36.1 \pm 5.4$ & $28.2 \pm 6.3$ & $34.0 \pm 8.4$ & $24.6 \pm 2.4^{*}$ & $32.1 \pm 4.5$ \\
\hline \hline
\end{tabular}

* Significantly different from the value of control group $(p<0.05)$.

響をみると、フェルラ酸群の総 Chol に上昇の傾向がみ られるが，各群の間に有意差は認められない。また、コ 一七一酸群の HDL-Chol は対照群に対し有意に低い。 しかし, 他の群の HDL-Chol 值には有意差はなく、フ エノールカルボン酸 $0.2 \%$, クメストロール $50 \mathrm{ppm}$ 以 下の含量では血清 Chol に対する影響はほとんどないと 考えられる。Sharma ${ }^{24)}$ はChol $1 \%$ 含有飼料にp-クマ 一ル酸を $0.15 \%$ 添加し，ラットに 12 週間にわたって給 与したところ，血清総 Chol が降下したことを報告して いる。Chol をラットに給与寸ると肝蔵における酢酸か らの Chol 合成が著しく抑制され，さらに長期間の Chol 投与はメバロン酸からの合成にも大きく影響することが 知られているので25), 飼料組成と飼育期間の差異が Sharma とわれわれの結果に違いを生した原因と考兄ら れる。また, Béguin と Kincaid は26) 脱脂大豆からな る無 Chol 飼料にクメストロールを $50 \mathrm{ppm}$ 混合した飼 料で, ニワトリヒナを 21 日間飼育したところ血漿 Chol が降下したと述べており，われわれのラットによる実験 とは異なる結果となっている。このように, フェノール カルボン酸およびクメストロールに血清 Chol 降下作用 があるとする報告もあるが，今回のわれわれの実験条件 では降下作用は認められなかった。また，フェノールカ ルボン酸の毒性23), アルファルファLPに含をれるクメ ストロールの測定値 516$)$ から考光, 今回飼料へ添加したそ れぞれの化合物の量は LP に含まれるフェノールカルボ ン酸, あるいはクメストロール量を十分超えていると推 定される。それゆえ，われわれの結果に基づいて論ずれ ば, LP にフェノールカルボン酸やクメストロールが混 在しているとしても，それらの影響をほとんど無視でき るものであり, LP の Arg/Lys 比, Met+Cys/Gly 比 が大豆タンパク質のそれらと近似していることと考兄合 わせ, LP の血清 Chol 降下作用は大豆タンパク質に類
似のものと判断される。なお, イタリアンライグラス, アルファルファ両 LP ともに血清 Chol 降下作用を示し たことは，LP のアミノ酸組成が原料の草種により大き く変動しない27)ことから理解される。

$$
\text { 要約 }
$$

イタリアンライグラスおよびアルファルファから緑葉 タンパク質 (LP) を調製し，血清 Chol 降下作用につい て，カゼイン，大豆タンパク質と比較検討した。これら タンパク質試料を，タンパク質レペル $20 \%$ になるよう に無 Chol ・低脂肪飼料に混合し，ウィスター系雄ラッ トに 21 日間給与した。両 LP 給与群とも, 血清総 Chol, LDL-Chol 濃度はカゼイン群に対し有意に低く, 大豆タ ンパク質群に近かった。肝臓の Chol 総量は大豆タンパ ク質群が最も少なく,つついてLP群で, カゼイン群が 最も大きく, 肝 Chol 総量と血清 $\mathrm{Chol}$ 濃度とは関連あ るものと思われた。LPに混在していると推測された $p$ クマール酸, フェルラ酸, コーヒー酸を無 $\mathrm{Chol} ・$ 低脂 肪飼料に $0.2 \%$ 添加した場合およびアルファルファ LP に混在すると考えられるクメストロールを $50 \mathrm{ppm}$ 添加 した場合、ラットの血清 Chol 濃度には影響をおよぼさ なかった。また, 両 LP の Arg/Lys 比, Met + Cys/Gly 比は大豆タンパク質のそれらに近似していた。これらの 結果から、イタリアンライグラスおよびアルファルファ LP の血清 Chol 降下作用は大豆タンパク質と類似のも のと判断された。しかし，LP の粗タンパク質含量，見 かけの消化率が低いことなど今後検討すべき点も示され た。

本研究は文部省科学研究費補助金 (No. 59360036, 代 表者：田先威和夫）による研究の一部である。 


\section{文献}

1) Sirtori, C.R., Agradi, E., Conti, F., Mantero, O. and Gatti, E. : Lancet, 1, 275 (1977)

2) Wolfe, B., Giovanetti, P., Cheng, D.C.H., Roberts, D.C.H. and Carroll, K.K. : Nutr. Rep. Int., 24, 1187 (1981)

3) Goldberg, A.P., Lim, A., Kolar, J.B., Grundhauser, J.J., Steinke, F.H. and Schonfeld, G. : Atherosclerosis, 43, 355 (1982)

4) Horigome, T. and Uchida, S. : Jpn. J. Zootech. Sci., 51, 429 (1980)

5) Knuckles, B.E., Fremery, D. and Kohler, G.O. : J. Agric. Food Chem., 24, 1177 (1976)

6) Rambourg, J.C. and Monties, B.: Qualitas Plantarum, 33, 169 (1983)

7) Pearson, S., Stern, S. and McGavack, T.H.: Anal. Chem., 25, 813 (1953)

8）堀太郎, 杉田陸海: 生化学実駼講座 3. 脂質の 化学 (日本生化学会編), 12 (1974), 東京化学同 人 (東京)

9) 永原太郎, 岩尾裕之, 久保彰治 : 食品分析法, 107 (1964), 柴田書店 (東京)

10）沖田卓雄, 菅野道廣：栄養と食糧, 32, 297(1979)

11) Kritchevsky, D., Tepper, S.A., Czarnecki, S.K. and Klurfeld, D.M. : Atherosclerosis, 41, 429 (1982)

12) Park, M.S. and Liepa, G. : J. Nutr., 112, $1892(1982)$

13) Katan, M.B., Vroomen, L.H.M. and Hermus, R.J.J. : Atherosclerosis, 43, 381 (1982)

14) Sugiyama, K., Ozawa, M. and Muramatsu, K.: J. Nutr. Sci. Vitaminol., 31, 121 (1985)

15) Sugiyama, K., Kushima, Y. and Muramatsu,
K. : Agric. Biol. Chem., 49, 3455 (1985)

16）堀米隆男：日畜会報，53，1 (1982)

17) Humphries, C. : J. Sci. Food Agric., 31, 1225 (1980)

18) Neves, L.B., Clifford, C.K., Kohler, G.O., Fremery, D.D., Knuckles, B.E., Cheowtirakul, C., Miller, M.W., Weir, W.C. and Clifford, A.J. : J. Nutr., 110, 732 (1980)

19) Nagata, Y., Imaizumi, K. and Sugano, M. : Br. J. Nutr., 44, 113 (1980)

20) Sautier, C., Flament, C., Doucet, C. and Suquet, J.P. : Nutr. Rep. Int., 34, 1051 (1986)

21) Bassat, M. and Mokady, S. : Br. J. Nutr., 53, 25 (1985)

22) Carroll, K.K. : Federation Proc., 41, 2792 (1982)

23) Jung, H.J.G. and Fahey, G.C. : J. Nutr., 113, 546 (1983)

24) Sharma, R.D. : Lipids, 14, 535 (1979)

25) Gould, R.G. and Swyryd, E.A. : J. Lipid Res., 7, 698 (1966)

26) Béguin, D.P. and Kincaid, R.L. : Poultry Sci., 63, 686 (1984)

27) Byers, M. : Leaf Protein Concentrates (Telek, L. and Graham, H.D., eds.), 145 (1983), AVI Publishing Company, Inc. (Westport, U.S.A.)

28) Phillips, P.H. and Hart, E.B. : J. Biol. Chem., 109, 657 (1935)

29) National Research Council : Nutrient Requirements of Laboratory Animals, 2nd revised ed. (1972) National Academy of Sciences (Washington, D.C.)

（1987 年 8 月 22 日受理） 